\title{
A Possible Paleoindian/Early Archaic Point from Ladyville, Belize, Central America
}

Stemp, W. James; Awe, Jaime J.; Helmke, Christophe

Published in:

PaleoAmerica

DOI:

10.1179/2055557115Y.0000000009

Publication date:

2016

Citation for published version (APA):

Stemp, W. J., Awe, J. J., \& Helmke, C. (2016). A Possible Paleoindian/Early Archaic Point from Ladyville, Belize, Central America. PaleoAmerica, 2(1), 70-73. https://doi.org/10.1179/2055557115Y.0000000009 


\section{PaleoAmerica}

A journal of early human migration and dispersal

ISSN: 2055-5563 (Print) 2055-5571 (Online) Journal homepage: http://www.tandfonline.com/loi/ypal20

\section{A Possible Paleoindian/Early Archaic Point from Ladyville, Belize, Central America}

\section{W. James Stemp, Jaime J. Awe \& Chistophe G. B. Helmke}

To cite this article: W. James Stemp, Jaime J. Awe \& Chistophe G. B. Helmke (2016): A Possible Paleoindian/Early Archaic Point from Ladyville, Belize, Central America, PaleoAmerica

To link to this article: http://dx.doi.org/10.1179/2055557115Y.0000000009

曲 Published online: 07 Apr 2016.

Submit your article to this journal $๘$

Q View related articles $\asymp$

View Crossmark data $\subset$ 


\title{
A Possible Paleoindian/Early Archaic Point from Ladyville, Belize, Central America
}

\author{
W. James Stemp
}

Keene State College, Keene, NH

\section{Jaime J. Awe}

Northern Arizona University, Flagstaff, AZ

\section{Chistophe G. B. Helmke}

University of Copenhagen, Copenhagen, Denmark

A biface fragment (JuaD/98/12/1) was recovered in 1998 as a surface find near Ladyville in northern Belize, Central America. Based on morphological and technological criteria, this biface is most likely preceramic and might date to the Late Paleoindian/Early Archaic period (ca. 10,000-8,000 cal yr BP). To distinguish this point fragment from the two lanceolate, Clovis-style bifaces from Ladyville, we have tentatively designated it Ladyville Wide Stemmed.

Keywords Paleoindian/Early Archaic, stemmed biface, Belize, Ladyville

Evidence for Paleoindian and Archaic huntergatherers in Mesoamerica is mainly represented by lithic artifacts, although the skeletal remains of fauna, including extinct Pleistocene mammals, preserved plant tissues, phytoliths, and pollen have also been critical to understanding early adaptations and subsistence strategies in this part of the world (Acosta Ochoa 2012; Rosenswig 2015; Zeitlin and Zeitlin 2000). When recovered as surface finds or in the absence of radiocarbon dates, chipped stone points with diagnostic features have typically been used to identify some of these sites as preceramic. In general, fluted bifaces in Mesoamerica have been assigned to the Paleoindian period (ca. 13,500-10,000 cal yr BP), while the introduction of stemmed points is associated with the beginning of the Archaic (ca. 10,000 cal yr BP).

Added to the inventory of bifacial points from Mesoamerica is a biface fragment (JuaD/98/12/1) recovered by Mr Juan Dorado in 1998 as a surface find near Ladyville Village in northern Belize, Central America (Figure 1). This artifact was registered and accessioned by the Institute of Archaeology in Belize and is presently curated in the governmental antiquities collection in Belmopan. It is a large, stemmed proximal biface fragment made

Correspondence to: W. James Stemp. Email: jstemp@keene.edu from what appears to be fine-grained chert. Due to the heavy surface patination of the artifact, the specific chert source cannot be determined. Nevertheless, considering that Ladyville is situated at the southern extent of the Northern Belize Chert-Bearing Zone, it seems most likely that this biface is made of locally procured chert. The fragment measures $127.3 \mathrm{~mm}$ long and $63.3 \mathrm{~mm}$ wide, but may have been around $200.0 \mathrm{~mm}$ in length when complete, making it larger than any known Paleoindian point from Belize (Table 1). The blade of the biface has straight, parallel edges that begin to taper slightly near the distal end break. The biface was flaked using soft-hammer percussion to produce the long, flat flakes that cross the midline of the tool as seen on other Paleoindian points (see Callahan 1979; Lohse et al. 2006, 216). Some flake scars extend almost to the opposite edge of the blade portion (Bradley et al. 2010). Although both edges were pressure flaked, neither was deliberately serrated nor alternately beveled due to resharpening, as seen on Late Archaic points from Belize (Kelly 1993; Lohse et al. 2006). The straight-sided stem was produced using a corner-notching technique characterized by a small Hertzian cone that created broad notch openings and distinct shoulders. The basal end-thinning of the stem was accomplished by removing multiple flakes from both faces, although the 


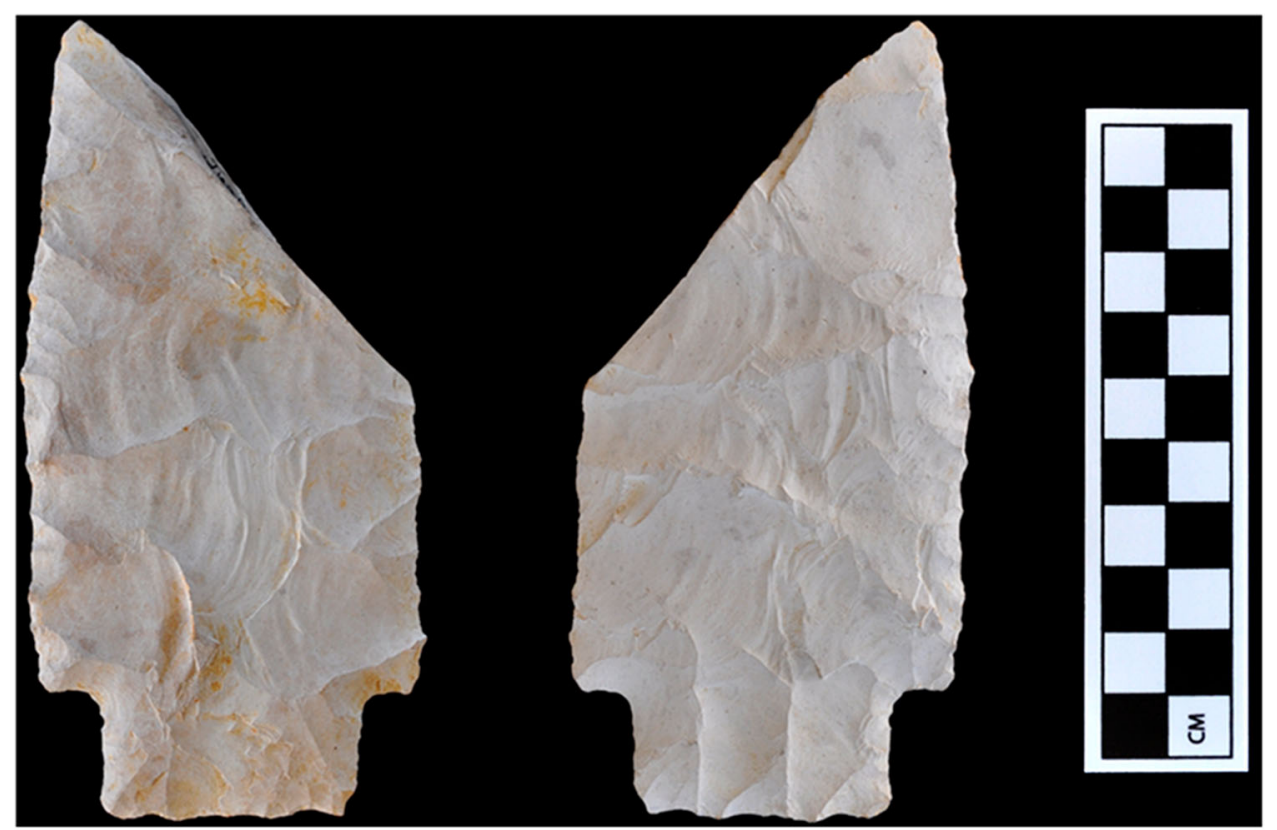

Figure 1 The Ladyville Wide Stemmed (JuaD/98/12/1) biface fragment. Photographs by Jaime Awe.

thinning flakes are better defined on one face. The diagonal (perverse) fracture across the blade section of the point is suspected to be the result of a manufacturing error (Crabtree 1972, 82-83; Whittaker 1994, figure 8.33). As such, this point may not represent a completely finished specimen, but it was likely close to completion based on the ratio of blade width to thickness (6.6:1), which falls within Callahan's (1979, table 5) stage 5+ range for experimental replicas of fluted bifaces, as well as the basal end-thinning/channeling of the stem and some edge retouch (Callahan 1979, figure 67e, f). The lack of grinding of the stem edges or base lends further credence to the suggestion that this biface was unfinished.
The JuaD/98/12/1 biface fragment is different from the seven known Paleoindian points from Belize; however, none of these points have been conclusively dated (Kelly 1993; Lohse et al. 2006) (Figure 2). Given the lack of associated radiocarbon dates for these points, they have been assigned to this period based on their technological and stylistic similarities to point types from North and South America, specifically Clovis and Fell's Cave. Four of these bifaces from Belize have been classified as fluted, fishtail (Fell's Cave-style) points. These points were recovered along the New River Lagoon (Pearson and Bostrom 1998), from around Orange Walk Town (MacNeish and Nelken-Terner 1983), at

Table 1

Metric data for the seven known Paleoindian points from Belize (Lohse et al. 2006, 215, table 1) and the JuaD/98/12/1 point

\begin{tabular}{|c|c|c|c|c|c|c|c|}
\hline & Length (mm) & $\begin{array}{l}\text { Max. } \\
\text { width } \\
(\mathrm{mm})\end{array}$ & $\begin{array}{l}\text { Width at } \\
\text { shoulder } \\
(\mathrm{mm})\end{array}$ & $\begin{array}{l}\text { Width at } \\
\text { waist* }^{*} \\
(\mathrm{~mm})\end{array}$ & $\begin{array}{l}\text { Width at } \\
\text { base } \\
(\mathrm{mm})\end{array}$ & $\begin{array}{l}\text { Thickness } \\
(\mathrm{mm})\end{array}$ & $\begin{array}{l}\text { Max. } \\
\text { width:thickness } \\
\text { ratio }\end{array}$ \\
\hline $\begin{array}{l}\text { New River Lagoon } \\
\text { fishtail }\end{array}$ & 69.6 & 52.6 & 44.5 & 26.9 & 21.6 & 7.9 & $6.6: 1$ \\
\hline Big Falls fishtail & 43.0 & 28.8 & 28.8 & 25.6 & 21.4 & 6.2 & $4.6: 1$ \\
\hline $\begin{array}{l}\text { Orange Walk } \\
\text { fishtail }\end{array}$ & 70.4 & 46.7 & 37.1 & 23.0 & 20.5 & - & - \\
\hline $\begin{array}{l}\text { Lowe Ranch } \\
\text { fishtail }\end{array}$ & 69.6 & 46.5 & 40.4 & 25.7 & 19.3 & - & - \\
\hline $\begin{array}{l}\text { BAAR 191/ } \\
\text { Ladyville } \\
\text { lanceolate }\end{array}$ & - & - & - & - & 29.6 & - & - \\
\hline $\begin{array}{l}\text { Ladyville } \\
\quad \text { lanceolate }\end{array}$ & 91.6 (incomplete) & 35.9 & 35.9 & 33.5 & 27.7 & 8.3 & 4.3:1 \\
\hline $\begin{array}{l}\text { August Pine Ridge } \\
\text { lanceolate }\end{array}$ & 51.6 & 26.1 & 26.1 & 19.6 & 20.4 & 6.0 & $4.4: 1$ \\
\hline $\begin{array}{l}\text { Ladyville Wide } \\
\text { Stemmed } \\
\text { (JuaD/98/12/1) }\end{array}$ & 127.3 (incomplete) & 63.3 & 60.5 & 41.1 & 40.9 & 9.6 & $6.6: 1$ \\
\hline
\end{tabular}

*Immediately below shoulder. 


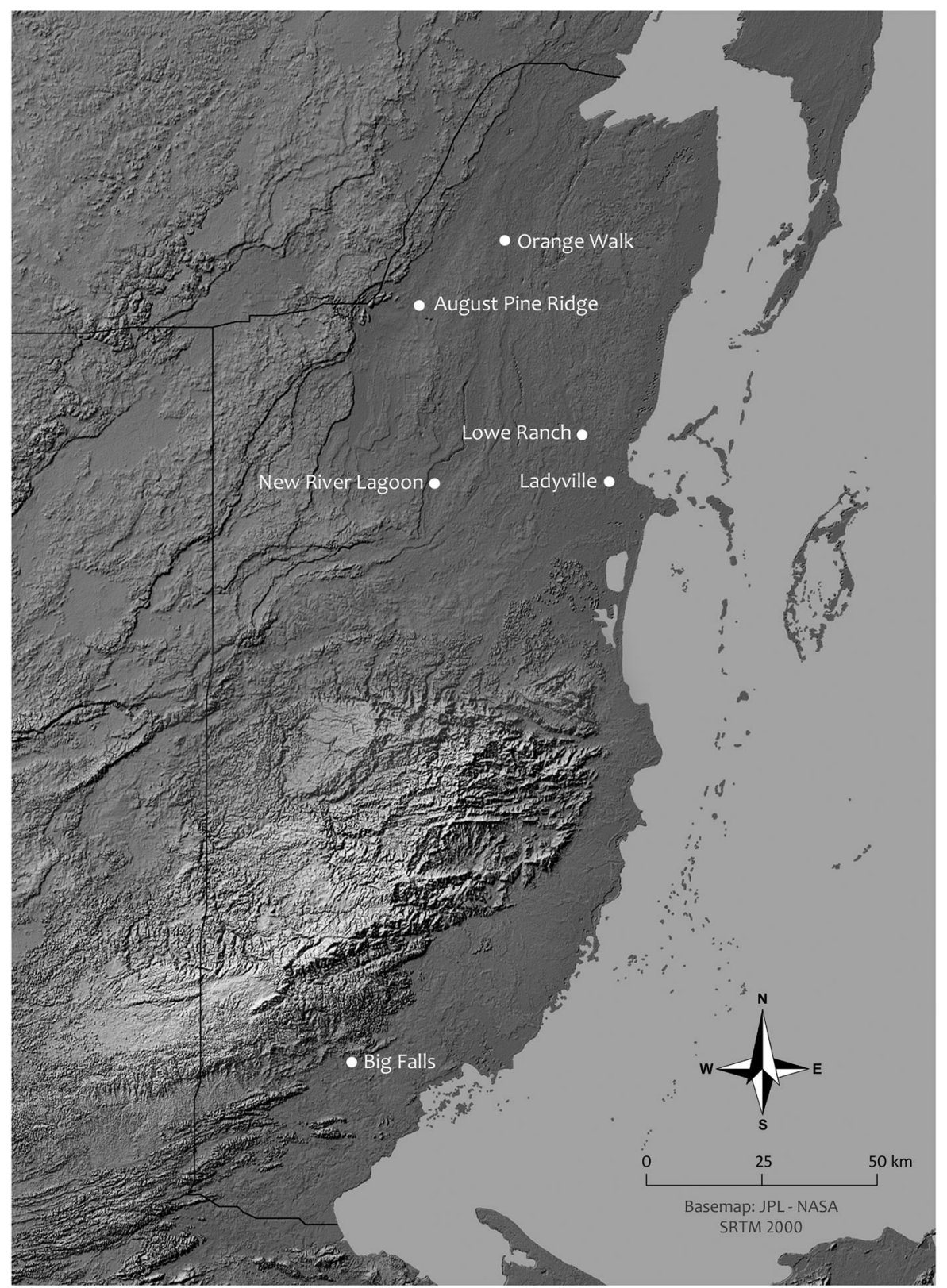

Figure 2 Map of Belize showing the locations of the seven Paleoindian points and the Wide Stemmed Ladyville (JuaD/98/12/1) point. Map by Christophe Helmke.

Lowe Ranch (MacNeish et al. 1980), and along the Rio Grande near Big Falls in southern Belize (Weintraub 1994) (Figure 2). Lohse et al. (2006, 215) describe the fishtail points as having "broad unbarbed shoulders, rounded tips, narrow stems with slightly outcurving 'ears,' and concave bases that are thinned by fluting or channel flakes." The examples from Belize all have a single flute on each face (Lohse et al. 2006, 215). The other three bifaces have been classified as fluted, lanceolate (Clovis-style) points. One is from the site of Ladyville (Hester et al. 1981), the second was found near Ladyville (MacNeish and Nelken-Terner 1983), and the third was recovered around August Pine Ridge in northern Belize (Valdez and Aylesworth 2005). In general, the lanceolate points from Belize possess slightly convex edges beginning about a third of the way from the base with a mildly narrowing waist and weak outward flaring at the base (Kelly 1993, 210; Lohse et al. 2006, 216). The bases of all three points are concave. The Ladyville point recovered by Hester et al. (1981) and the point from August Pine Ridge are both fluted, once on one face and twice on the other (Lohse et al. 2006, 216). Lohse et al. (2006, 216) note that the August Pine Ridge lanceolate point has small out-flaring ears at the base and a slight narrowing of its waist like the fishtail points, suggesting that it may be an example of a point that combines elements of both the lanceolate and fishtail types. All of these points are heavily to completely covered in a white to off-white/yellow patina (see Kelly 1993, 210). 
Based on morphological and technological criteria, we believe the JuaD/98/12/1 biface fragment is preceramic. We have tentatively assigned it a new designation - Ladyville Wide Stemmed - to differentiate it from the two currently known lanceolate points from Ladyville. The fact that some of the artifact's traits are similar to those on the Paleoindian points from Belize leads us to believe that this artifact may date to the Late Paleoindian/Early Archaic period (ca. 10,000-8,000 cal yr BP). Moreover, some traits are similar to those on early preceramic points from North America (Justice 1987). Although this biface fragment is stemmed, it is also different from the stemmed and barbed points from the Late Archaic in Belize and all Maya Preclassic, Classic, and Postclassic point types (Lohse et al. 2006; MoholyNagy 2003; Rovner and Lewenstein 1997; Shafer and Hester 1983; Stemp and Awe 2013; Willey et al. 1965).

This newly identified fragment from Ladyville adds to the inventory of sites with Paleoindian points extending from Sonora, Mexico, to Panama. In Mesoamerica, fluted lanceolate and fishtail points have been recovered from a number of locations, including: Chapala-Zacoalco, Jalisco, Mexico; Sierra Gorda, Queretaro, Mexico; Oyapa, Hidalgo, Mexico; the Valley of Oaxaca, Mexico; Los Grifos cave in highland Chiapas, Mexico; Los Tapiales, San Rafael, and other sites in the Quiche basin of highland Guatemala; La Esperanza and El Gigante rockshelter in highland Honduras; Turrialba, Costa Rica; and the previously mentioned locations in Belize (Acosta Ochoa 2012; Rosenswig 2015; Zeitlin and Zeitlin 2000). It is worth noting that, although crude stone tools were found at Loltun Cave in the Yucatan Peninsula of Mexico, no points were recovered. Some levels at the site are considered Paleoindian based on the associated remains of extinct fauna (Zeitlin and Zeitlin 2000, 62). Although the Ladyville Wide Stemmed point shares some characteristics with most Paleoindian points from Mesoamerica, specifically fluting/channeling to thin the base and/or bifacial flaking across the midline of the blade portion, it is also a unique specimen because of its large size and wide stem. This point is also significantly different from the unfluted and non-stemmed leaf-shaped (Lerma-style) points from Mexico and Guatemala (Acosta Ochoa 2012, 133-34). As more Paleoindian sites are discovered throughout Mesoamerica, a better understanding of how the Ladyville Wide Stemmed point fits into the technology and chronology of the preceramic will surely develop.

\section{Acknowledgements}

The authors thank Mr Dorado for registering this point with the Institute of Archaeology (IOA) in Belize. The authors also express their gratitude to the directors and staff at the IOA who provided access to the point for study and have greatly assisted them in numerous ways with their research into the preceramic period of Belize.

\section{References}

Acosta Ochoa, G. 2012. "Ice Age hunter-gatherers and the colonization of Mesoamerica." In Oxford Handbook of Mesoamerican Archaeology, edited by D. L. Nichols and C. A. Pool, 129-140. New York: Oxford University Press.

Bradley, B., M. Collins, and C. Hemmings. 2010. Clovis Technology. Ann Arbor: International Monographs in Prehistory, Archaeological Series 17.

Callahan, E. 1979. "The basics of biface knapping in the eastern fluted point tradition: A manual for flint knappers and lithic analysts." Archaeology of Eastern North America 7(1): $1-180$.

Crabtree, D. E. 1972. An Introduction to Flintworking. Pocatello: Idaho State University Museum, Occasional Papers No. 28.

Hester, T. R., T. C. Kelly, and G. Ligabue. 1981. A Fluted PaleoIndian Projectile Point from Belize, Central America. San Antonio: University of Texas, Working Papers in Archaeology No. 1, Center for Archaeological Research.

Justice, N. D. 1987. Stone Age Spear and Arrow Points of the Midcontinental and Eastern United States: A Modern Survey and Reference. Bloomington: Indiana University Press.

Kelly, T. C. 1993. "Preceramic projectile-point typology in Belize." Ancient Mesoamerica 4(2): 205-227.

Lohse, J. C., J. Awe, C. Griffith, R. M. Rosenswig, and F. Valdez, Jr. 2006. "Preceramic occupations in Belize: Updating the Paleoindian and Archaic record." Latin American Antiquity 17(2): 209-226.

MacNeish, R. S., and A. Nelken-Terner. 1983. Final Annual Report of the Belize Archaic Archaeological Reconnaissance. Andover: R. S. Peabody Foundation for Archaeology.

MacNeish, R. S., J. K. Wilkerson, and A. Nelken-Terner. 1980. First Annual Report of the Belize Archaic Archaeological Reconnaissance. Andover: R. S. Peabody Foundation for Archaeology.

Moholy-Nagy, H. 2003. The Artifacts of Tikal: Utilitarian Artifacts and Unworked Material. Philadelphia: University of Pennsylvania Museum of Archaeology and Anthropology, Tikal Report No. 27, Part B. University Museum Monograph 118.

Pearson, G. A., and P. Bostrom 1998. "A new fluted stemmed point from Belize and its implications for a circum-Caribbean Paleoindian culture area." Current Research in the Pleistocene 15: 55-57.

Rosenswig, R. M. 2015. "A mosaic of adaptation: The archaeological record for Mesoamerica's Archaic period." Journal of Archaeological Research 23(2): 115-162.

Rovner, I., and S. M. Lewenstein. 1997. Maya Stone Tools of Dzibilchaltun, Yucatan, and Becan and Chicanna, Campeche. New Orleans: Tulane University, Middle American Research Institute Bulletin 65.

Shafer, H. J., and T. R. Hester. 1983. "Ancient Maya chert workshops in northern Belize, Central America." American Antiquity 48(3): 519-543.

Stemp, W. J., and J. J. Awe. 2013. "Possible variation in the Late Archaic period bifaces in Belize: New finds from the Cayo District of western Belize." Lithic Technology 38(1): 17-31.

Valdez, Jr., F., and G. Aylesworth. 2005. "A fluted Paleoindian point and other chipped stone tools from August Pine Ridge, Belize." Mono y Conejo 3: 35-39.

Weintraub, B. 1994. "Geographica." National Geographic 185(4), April.

Whittaker, J. C. 1994. Flintknapping: Making and Understanding Stone Tools. Austin: University of Texas.

Willey, G. R., W. R. Bullard, Jr., J. B. Glass, and J. C. Gifford. 1965. Prehistoric Maya Settlements in the Belize Valley. Papers of the Peabody Museum of Archaeology and Ethnology, Vol. 54. Cambridge: Harvard University

Zeitlin, R. N., and J. F. Zeitlin. 2000. "The Paleoindian and Archaic cultures of Mesoamerica." In The Cambridge History of Native Peoples of the Americas, Volume II: Mesoamerica, edited by R. Adams and M. Macleod, 45-121. Cambridge: Cambridge University Press. 